\title{
Encrypted Astronomy, Astral Mythologies, and Ancient Mexican Studies in Austria, 1910-1945
}

\section{Peter Rohrbacher}

- Institute for Social Anthropology, Austrian Academy of Sciences / Vienna, Austria

\section{ABSTRACT}

This paper examines the beginnings of Austrian studies on ancient Mexico by analyzing the work of Damian Kreichgauer and Friedrich Röck in the early twentieth century. Both argued that a priest elite intentionally "coded" astronomical data in ancient Mexican manuscripts. The first section of the article sheds light on the theoretical background of this interpretation. The main section, based on numerous archival sources, is dedicated to the deciphering procedure elaborated by Röck, the first director of the Ethnological Museum in Vienna (today Weltmuseum Wien). Since Röck's method seemed to revolutionize the discipline, it gained a great deal of attention from Cerman Nazi authorities. The final section deals with Röck's student Karl Anton Nowotny, who elaborated an ethnographic approach of ancient Mexican studies in Austria after World War II. This study provides new insights into the historical background of postwar ancient Mexican studies in Austria.

DOI

http://dx.doi.org/10.11606/ 2179-0892.ra.2019.157036

\section{KEYWORDS}

Ancient Mexican Studies, History of Anthropology, Diffusionism, Codex Vindobonensis I, National Socialism. 
Ancient Mexican studies has been an academic discipline in Austria since 1925. Albeit without a proper chair, Austrian ancient Mexican studies have been firmly established within the international scientific community with the work of Karl Anton Nowotny (1904-1978) and his student Ferdinand Anders (born 1930). 'The following article deals with the beginnings of this academic discipline in Austria and seeks to trace the historical foundation on how Ancient Mexican studies became a subdivision of post-war anthropology. Shortly before the First World War, Ancient Mexican studies evolved in Austria with a focus on astronomy and the calendar. Its foundations were laid by Damian Kreichgauer (1859-1940) and Friedrich Röck (1879-1953). Both advocated a diffusionist approach, arguing that Pre-Columbian Mexican manuscripts contain highly complex astronomical knowledge that was "coded" by a priest elite. In 1936, Röck introduced a new method for deciphering ancient Mexican manuscripts, which was widely accepted outside academia by the authorities of the Nazi period. The present article is based on archival documents not previously taken into consideration, as well as documents from an extensive collection of Röck's unpublished manuscripts. ${ }^{2}$

\section{ANCIENT MEXICAN STUDIES IN THE CONTEXT OF THE ASTRAL MYTH SCHOOLS}

Prior to the beginning of the twentieth century, mythologies had for a long time been ignored as a source genre by prevailing historicism. A change took place when a series of disciplines - led by classical studies, folklore studies, and ethnology - began to use myths, regarded as humanity's oldest sources, for the study of history (Frazer 1906-1915). In 1906, the German historians Ernst Siecke und Ceorg Hüsing established a Society for the Comparative Study of Myths in Berlin. This society, with its book series "Mythological Library" (1907-1916) created the institutional framework for an astral interpretation of myths and thus distanced itself from the predominantly philological approach of the time. In Vienna, a group of mythologists formed around Leopold von Schroeder, an Indologist from Latvia, became known as the Viennese School of Mythology and cooperated closely with folklore studies, which was not yet university based (Bockhorn, 1994: 488-495).

The astral myth interpretation, which can be traced back to the eighteenth century, ${ }^{3}$ was based on the idea that all mythology around the world was exclusively concerned with processes in the sky and the movements of the stars, especially with the movements of the sun, the moon, and Venus in relation to the twelve constellations of the zodiac. In this doctrine, the numbers of orbital periods of the planets and their relations to each other played a special role and they were seen as the origin for time divisions and calendar systems.

Against this theoretical background, the Catholic missionary Damian
1 Nowotny (1961); Anders Jansen; Carcía (1992); Boone (2007: 161-162). This article is the result of an extensive study of Friedrich Röck and other scholars in the period of Nazi domination. A separate version will be published as "Verschollene Kulturzusammenhänge': Der Altorientalist und Altamerikanist Friedrich Röck und seine Stellung in der NS-Zeit". In: Cingrich, Andre and Rohrbacher, Peter (eds.) Völkerkunde zur NS-Zeit aus Wien (1938-1945): Institutionen, Praktiken und Biographiezentrierte Netzwerke. Wien: Österreichische Akademie der Wissenschaften (forthcoming). This study was supported by the Faculty of Social Sciences at the University of Vienna. For suggestions to improve this article I thank Han F. Vermeulen

2 Röck's private papers and handwritten manuscripts are housed in more than boxes and are preserved at Vienna University Archive (henceforth abbreviated as VUA), partially evaluated by Peter Linimayr (Linimayr, 1993/2: Q33-Q157; Linimayr, 1994: 87-116).

3 Buchwald and Josefowicz (2010: 28-31; 47-69) 
Kreichgauer gave a celebrated lecture, "Les Mythologies et les calendriers de l'ancien Mexique", at Louvain (Belgium) in September 1913 during the "Religious-Ethnological Weeks" organized by Pater Wilhelm Schmidt. His contribution to the conference also formed the prelude to the academic profession of ancient Mexican studies in Austria (Kreichgauer, 1914: 315-333). As a trained physicist, Kreichgauer had first been a research assistant to Hermann von Helmholtz in Berlin-Charlottenburg, but in 1892 joined the Steyler Missionaries and moved to Austria (Kraus, 1962: 31). As a missionary priest, he combined his extraordinary

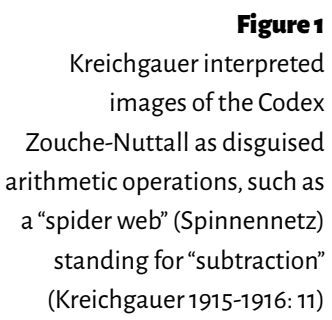

Figure 1

Kreichgauer interpreted images of the Codex

Zouche-Nuttall as disguised arithmetic operations, such as a "spider web" (Spinnennetz) standing for "subtraction" (Kreichgauer 1915-1916: 11) mathematical knowledge with cultural studies and applied these to the pre-Columbian cultures of America. Working as an autodidact in this field, Kreichgauer based his work on that of Eduard Seler, the German founder of ancient American studies in Berlin. Seler's pioneering astronomical interpretations of the Codex Borgia (Seler 1904-1909) formed the starting point for Kreichgauer's investigations of the Codex Zouche-Nuttall. In 1916 Kreichgauer concluded that this ancient Mexican picture manuscript contained highly complex astronomical knowledge, which had intentionally been encrypted by a priest elite. Unlike Seler, Kreichgauer believed that mythological images served the sole purpose of distracting from the actual astronomical data in order to protect it from misuse by outsiders (Kreichgauer, 1915-1916: 1). For example, Kreichgauer interpreted images as disguised arithmetic operations, such as a "spider web" standing for "subtraction" (Ibid.: 11-12). He argued that Seler had ignored this "skill in secrecy" (Ibid.: 2) and Kreichgauer continued his research by studying the Codex Vindobonen-

Zeichen für die Subtraktion fehlt. Wir erhalten also in zweiter Annäherung $72^{a} 113^{d}+9^{a} 80^{d}=81$ Jahre 193 Tage. In der Reihe treten aber noch zwei weitere Korrektionen auf. Zunächst finden wir hier zum zweitenmal eine Anzahl einzeln stehender, unbeschäftigter Götter. Es sind die sieben Personen auf Seite 23 links oben uber dem Spinnennetz, und die zwei unten in der Mitte befindlichen Gestalten, zwischen denen ein zweites Spinnennetz gezeichnet ist. Das Spinnennetz schreibt die Subtraktion vor. Dazu kommt eine ganz neue Korrektion, die wir aber später noch zweimal antreffen werden, nämlich 20 Punkte um einen Jaguarkopf auf Seite 24. Uberall, wo diese letztere Korrektion vorkommt, muß sie subtrahiert werden. Wir kommen somit schlieBlich zu dem Resultate 81 Jahre 164 Tage, genau wie in Reihe $A$.

Reihe $D$.

Ohne deutliches Kennzeichen beginnt am Ende der Seite 6 eine dritte Reihe über die mittlere Dauer von 50 Venusperioden. Das normale Ausgangsdatum fehlt; wenn man es ergănzt, ist sie zusammengesetzt wie folgt:

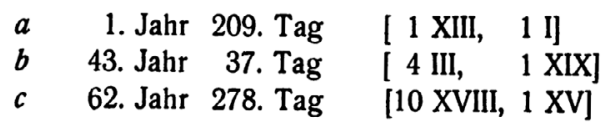

Das rohe Resultat betrăgt 61 Jahre 69 Tage. Daran sind zwei Arten von Korrektionen anzubringen, von denen die eine schon in den Reihen $C$ und $L$ aufgetreten ist. Hinter den auf Seite 6 zur Reihe $C$ gehörigen einzelnen Götterfiguren, die alle nach rechts gewendet sind, beginnt nämlich eine neue Gruppe

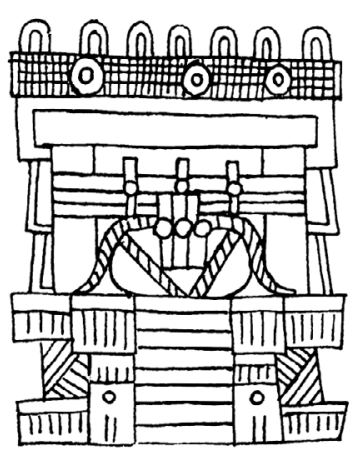
Abb. 7. von ganz entsprechenden zwölf Einzelgöttern, aber mit der Blickrichtung nach links. Das Spinnennetz zeigt an, daß die Anzahl dieser Figuren vom rohen Resultat abgezogen werden muB; diese Operation führt uns zu der Zahl $61^{a} 57^{d}$. Die zweite Korrektion ist neu; aber auch sie wird, wie alle die vielen anderen Arten im Laufe der Untersuchung wieder auftreten: Auf Seite 8 sieht man einen sorgfăltig gezeichneten Tempel des zunehmenden Mondes mitten im Texte und ohne Beziehung zu seiner Nachbarschaft (Abb. 7): Ein solcher hat als Korrektionsglied den Wert von 30 Tagen (Dauer des synodischen Monates). Auf Seite 7 links oben steht aber ein Spinnennetz mit einer Hand, die auf den Tempel hinzeigt. Da wir schon aus mehreren Fälen das Netz als Zeichen der Subtraktion kennen, so ziehen wir 30 Tage von $61^{a} 57^{d}$ ab und gelangen zum SchluBresultat 61 Jahre 27 Tage.

Um den Zusammenhang mit den beiden vorigen Reihen mehr hervorzuheben, verwandeln wir die Tage in Bruchteile des Jahres und finden für $A$ und $M 81.45$ Jahre, und hier 61.07 Jahre. Es ist aber auch $81.45 \times 8 \%=61.09$. 
sis I. His studies reaffirmed that "astronomer priests", "had written all necessary data into the interstices of a series of mythological images" (Kreichgauer, 1917: 7). Kreichgauer published his results in 1917 at the Imperial Academy of Sciences, yet the work, while being well promoted, was ignored for the next decade.

\section{PAN-BABYLONISM, ELAMISM AND THEOSOPHY}

The followers of "pan-Babylonism"4 were an important subgroup of astral mythologists that regarded ancient Babylon as the culture-historical starting point of the astral system. According to them, this system was fully developed by around $3,000 \mathrm{BC}$ and first spread across the ancient Orient, then finally around the entire globe. Pan-Babylonists argued that religion comprised specialized astronomical secrets passed on to the "common people" in the form of myths. This theory was mainly based on the astronomical knowledge of the precession of the Earth's axis with its long cycle of about 26,000 years ("Platonic Year"). The history of astronomy teaches, however, that the Greek mathematician Hipparchos of Nicaea discovered precession in the second century $\mathrm{BC}$ and thus this phenomenon could not have been known in ancient Babylon (Hoskin, 1999: 18-47). For this reason, pan-Babylonists were rightly exposed to heavy criticism from the beginning. ${ }^{5}$

From an early age, Friedrich Röck was in close contact with the pan-Babylonists. Born on July 14, 1879, in Imst, Röck came from an educated middle-class family in Tyrol. ${ }^{6}$ Nevertheless, in June 1904 he graduated late at the age of 25 from the Austrian Cymnasium Brixen. Subsequently, Röck studied Babylonian -Assyrian and Egyptian philology at the University of Innsbruck, as well as the history and cultural history of the ancient Near East. Röck's most important academic teacher was Thomas Friedrich, who had taken over the chair in Ancient Oriental Antiquities and History of the Ancient Near East at Innsbruck in 1908.7 Friedrich also supervised Röck's dissertation, which culminated in the writing of "Studies on Babylonian-Assyrian Mythology", with which he graduated from the University of Innsbruck in March 1911 (Röck, 1911). ${ }^{8}$

However, Röck's research interests were less influenced by the Assyriologist environment of the University of Innsbruck, than by astral-mythological schools of thought and pseudo-scientific theosophical circles. As a student, for example, he was looking for evidence to support the pan-Babylonist theory in ancient India, and in an article published in 1910 he argued that, "the entire Indian Yuga system" [...] was built on the 'Platonic number"' (Röck, 1910: 324). After graduation, Röck came under the influence of the "Elamists." Like Röck, they were völkisch-minded ${ }^{9}$ Assyriologists who attributed the emergence of the first written culture to ethnic "Aryans." Accordingly, they ascribed the origins of astral
4 On the history of "panBabylonism", see Weichenhan 2016: 19-72.

5 One of the best-known opponents of pan-Babylonism was Franz Xaver Kugler S], a German Assyriologist and astronomy historian, whose arguments were adopted by Father Wilhelm Schmidt and Leopold von Schroeder (Kugler, 1907: 38-50; Schmidt, 1908: 77)

$6 \operatorname{Kofler}$ (1975/I: 3) (Karl Röck, CV of our father Hermann Röck, Oct 1, 1950).

7 See https://www. uibk.ac.at/alte-geschichteorient/institutsgeschichte/ kurzgeschichte-altorientalistik html (accessed Oct 12, 2017).

8 According to the Archive of the University of Innsbruck, Röck's unpublished dissertation is lost.

9 The term völkisch has no direct English equivalent, but it could be rendered as hypernationalist sentiment allied with anti-Semitism 
theory not to ancient Babylon but to the even older Elam Empire, whose capital, Susa, is in present-day Iran. Among the most influential representatives among them were Ferdinand Bork and Ceorg Hüsing, who knew each other from their student days in Königsberg (now Kaliningrad). ${ }^{10}$

Bork was able to prove the rotation period of Venus was 225 days in the ancient Mexican calendar in 1910 (Bork, 1910: 83-105). According to a diffusionist approach, the origin of this knowledge was to be found in the Old World. "It's up to research," Bork stated, "to find the paths that lead from Elam to Mexico" (Bork, 1910: 102). With his pan-Elamite research, Ferdinand Bork opened a field of research to which Röck dedicated his entire life.

In an unpublished manuscript from 1912, Röck stated: "The evidence that Elamite cultural influence extended across almost all the world in prehistoric times is compelling." He showed that the ancient zodiac was not a Babylonian invention, as had previously been assumed, but much older, going back to ancient times. Röck expounded that the twelve-part zodiac was derived from an older zodiac system that distinguished eight constellations corresponding to the Elamite "system of eight" described by the völkisch mythologist Wolfgang Schultz. ${ }^{12}$ Just like the aforementioned pan-Elamists, Röck believed that "a significant portion of ancient Elam's culture can be traced back to Aryan tribes."13

Röck's younger brother Karl ${ }^{14}$, wrote extensive diaries, which are stored at the Research Institute Brenner-Archive in Innsbruck. ${ }^{15}$ These reveal a hitherto unknown side of the future museum director: According to his brother, Friedrich Röck was a devout theosophist, i.e., a supporter of mystical and occultist philosophy. For example, on December 24, 1919, Karl Röck noted: "Fritz is an active member [of the Theosophical Society]"16 and on December 11, 1920: "In the evening [I attended] the lecture of my brother Fritz at the Theosophical Society of Agrippa von Nettesheim on numerical symbolism. ${ }^{17}$ The Friedrich Röck papers contain a number of manuscript excerpts from works by Helena Petrovna Blavatsky and Annie Besant. ${ }^{18}$ These fragments show that Röck probably adopted the theory of the "Aryan zodiac," with its "immeasurably" old age, from Blavatsky's "Secret Doctrine," the most important work of nineteenth-century Western theosophy (Blavatsky, 1899/l: 713). ${ }^{19}$

\section{THE INSTITUTIONALIZATION OF ANCIENT MEXICAN STUDIES IN VIEN NA}

In November 1920, Röck became a research assistant at the Ethnographic Department of the Natural History Museum in Vienna. The head of this department was Viktor Christian, who liked the fact that Röck was a trained Assyriologist. However, Röck was assigned to the Americas section in this department and from that moment on he increasingly focused his studies on Mexico. During the next
10 Ferdinand Bork was a schoolteacher at the Löbenicht Realgymnasium in Königsberg. Not affiliated to any university, he developed into the leading Elamist until the post-war period (Weidner, 1963: 304). pears, pears do not want to fall 1912: 1-16, here 15, unpublished manuscript.

12 Ibid., here 15; Röck (1913: 147-176); see Schultz (1910: 101150) and Bork (1914: 66).

13 Ibid., here 16.

14 Karl Röck was an employee of the literary magazine Brenner and was one of Ceorg Trakl's closest friends. In 1925 after Trakl's death, he published the first complete edition of Trakl's poems

15 For this note I thank Ildikó Cazan, Vienna. Karl Röck's diaries are already published (Kofler 1975/I-III).

$16 \operatorname{Kofler}$ (1975/I: 317) Karl Röck, diary entry, Dec 24, 1919.

17 Kofler (1975/l: 334) Karl Röck, diary entry, Nov 4, 1920; see also Röck (1915); Nowotny 1967).

18 VUA, FRP, 131.104.21; excerpts to Helena P. Blavatsky "The Secret Doctrine" (Engl. orig. 1877) and Annie Besant "The Seven Principles of Man" (Engl. orig. 1892).

19 Theosophists believe that Aryans descended from the sunken continent Atlantis. 


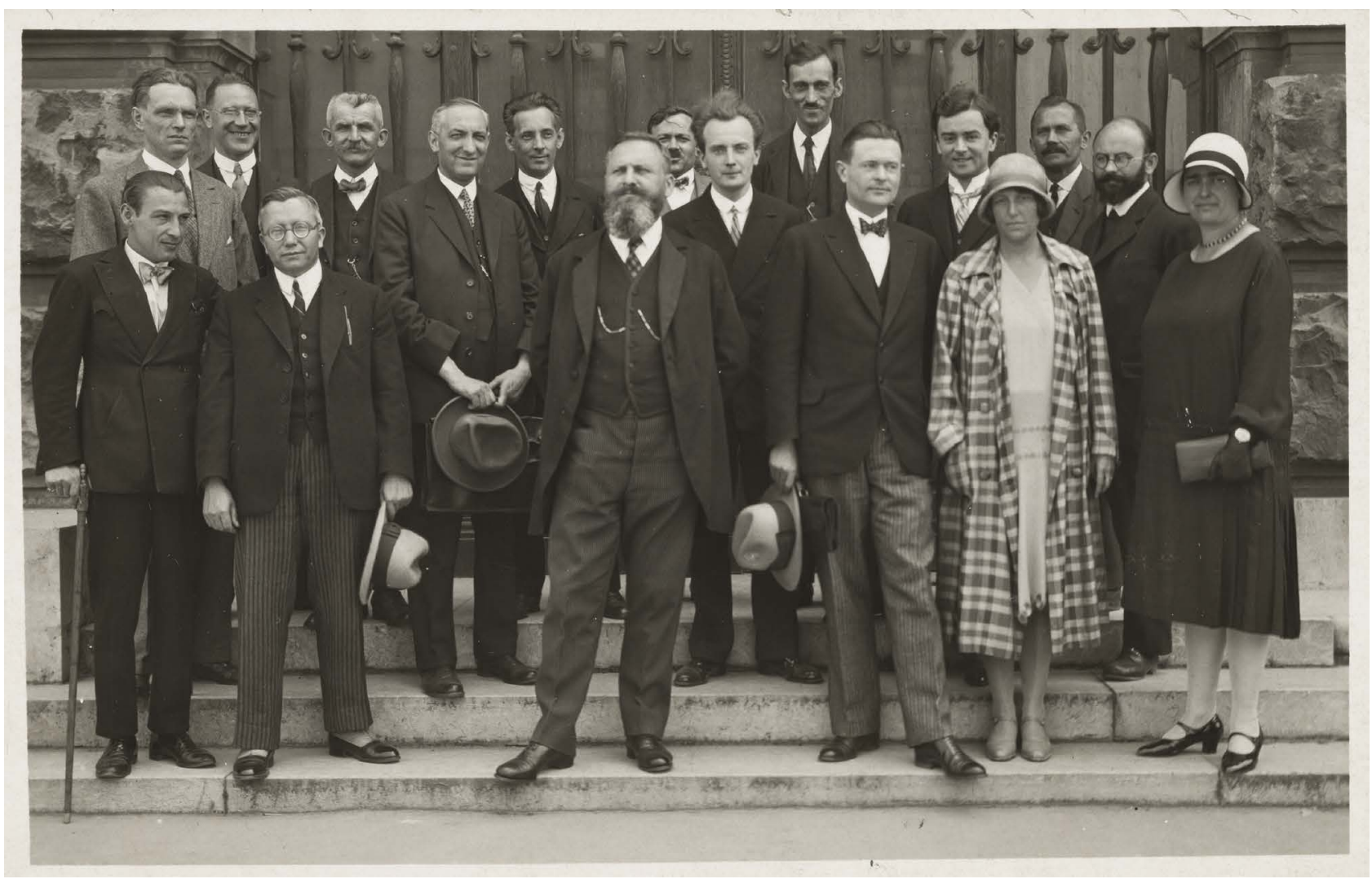

decade, Röck was able to build a considerable academic career. In March 1925 he received permission from the University of Vienna to teach the subject "Ethnology with Special Attention to American Linguistics and Antiquity". When Christian moved to the University of Vienna, Röck took over leadership of the Ethnographic Department at the Natural History Museum in December 1925. In this capacity, he supervised the relocation of the ethnographic collections to the Neue Burg Palace in 1927 and the following years. He became the first director of the Ethnological Museum in Vienna in 1928, a position he held until his discharge in 1945. In June 1931, Röck was appointed associate professor at the University of Vienna. ${ }^{20}$

Röck's professional transformation from Assyriologist to ancient Mexicanist was remarkable. He could not claim to have had a relevant education, but in one of his CVs stated that he in 1907 had "privately" studied "Ethnography and American studies." ${ }^{21}$ Like Kreichgauer, Röck was largely self-taught. His first step into serious ancient Mexican studies took place in 1917 when Röck set up a "Toltec star map" identifying "twenty-eight Toltec lunar houses." He interpreted them as an "ancient Mexican calendar scripture." ${ }^{22}$ On the one hand, the result was based on the professional calculations of the Viennese astronomer Friedrich Karl Ginzel, whose star map showed "lunar stations around 4000 BC" for the northern hemisphere. ${ }^{23}$ On the other hand, however, Röck had merely followed the unproven thesis that the German mythologist Eduard Stucken had presented
Figure 2

Director Friedrich Röck (center) with employees of the Ethnological Museum Vienna, 1930 (Private Archive Bettina Hainschink, Vienna)

VUA, PH PA 3.052. extensive student notebook for the academic year 1906/07 does not yet contain any entries to America (PA Anders; Röck, student notebook, 1906/07, 264 pages).

22 Röck designed this star map on Apr 25, 1917 (Röck, 1922: 134).

23 Cf. the star map in Ginzel (1906/I: appendix), Röck (1922: 134), and Röck (1925/l: 147). For this note, I thank Ferdinand Anders, Klosterneuburg. See also Steinle (1995: 133); Luksch (2015: 119-120). 
in his book "The Origin of the Alphabet and the Lunar Stations" (Stucken, 1913). Like Stucken and many other astral mythologists, Röck believed the "origins of Scripture" to be "in the sky" (Röck, 1919-1920: 1095).

In 1922, Röck argued in his habilitation thesis that elements of the Venus calendar as well as scripture in ancient Mexico "have their exact counterparts in the Old World" (Röck, 1922: 132). As evidence, he offered "traces of an old Venus calculation" on the basis of the Elamite "octagonal system," which he in the available codices interpreted as "octagram," "octagonal fickfack," and "octagonal radial star." ${ }^{24}$ Röck summarized the main results of his habilitation thesis as follows: "I therefore believe that the calendar systems, especially the Venus calendar, the entire belief in stars [...] of the ancient Mexicans are remnants of lost cultural relations with the Old World" (Röck, 1922: 132).

When Röck submitted his habilitation to the University of Vienna on March 8,1923 , the College of Professors at the Faculty of Philosophy had difficulty in its assessment; the first session was fruitless. ${ }^{25}$ Subsequently, an expert opinion was requested from Walter Lehmann, Director of the Ethnological Research and Education Institute of the Ethnological Museum of Berlin. He was Eduard Seler's most important student and gained his habilitation on the subject "American Language, Folklore and Antiquity Studies" in 1915. Lehmann's judgment was devastating. In a letter to the dean he stated that Röck advocated views "for example, about a planet order [...] with which neither my teacher Seler nor I can agree." ${ }^{26}$ Lehmann's extremely unfavorable report was read on February 8 , 1924 in the second commission meeting; however, it was ignored. "For personal reasons [I support Röck]," countered art historian Josef Strzygowski, an extreme Cerman nationalist. Thus, common agreement was reached among the College of Professors ${ }^{27}$ and Röck's application for the "Venia legendi" was accepted with five votes in favor and two abstentions. ${ }^{28}$ The protocol of the habilitation committee shows clearly that Röck, right from the start, enjoyed strong support from the Faculty of Philosophy of the University of Vienna, which was based less on professional competence, than on Cerman-national networks.

\section{RÖCK'S “DECIPHERING PROCEDURE" IN THE CONTEXT OF NATIONAL SOCIALIST SCIENCE POLICY}

Röck's preoccupation with ancient Mexican manuscripts received a new impetus when, in 1929, the Austrian National Library published the first complete facsimile edition of the famous Codex Vindobonensis I. However, not Röck but the aforementioned Walter Lehmann wrote the "technical introduction" (Lehmann, 1929: 13-42). Lehmann could not accept the evidence that Kreichgauer had presented for his astronomical "camouflage theory." In his introductory commentary,
24 Ibid.; see also Röck (19191920: 1092).

25 VUA, PH PA 3.052, folio (f.) 17; protocol of the College of Professors, Jan 24, 1924. See also the evaluation of Ranzmaier (2013: 238-239).

26 Franz Eduard Suess.

27 VUA, PH PA 3.052, $f$ 20; protocol of the College of Professors, Feb 8, 1924.

28 VUA, PH PA 3.052, f. 11; Schmidt, Feb 8, 1924, commission report to the dean; Paul Kretschmer abstained because Lehmann's letter contained nojudgment on Röck's linguistic works (Ranzmaier, 2013: 238). 
Lehmann noted that Kreichgauer's views were "not based on fixed facts," but merely "assumptions" (Ibid.: 19). Despite intensive studies, Lehmann admitted that he too, could not "comment exhaustively" on the "Viennese manuscript" (Ibid.). At this point, Röck began his ambitious seven-year engagement in order to discover the unknown meaning of the "Old Indian Picture Book," as he initially titled it (Röck, 1935: 193).

The deciphering technique developed by Röck was built on the work of Kreichgauer. However, Röck focused on the images and after a while he found "hidden ratios" in them that Kreichgauer had not seen. Using the rules of camouflage Röck identified "number pictures," as well as arithmetical operations of astonishingly precise astronomical calendar data (Ibid.: 199). He concluded that ancient Mexican astronomer priests had already been able to correctly calculate the orbital periods of the planets Venus, Mars, Mercury, Jupiter and Saturn on three and four decimal places. Consequently, Röck made an impassioned case for the recognition of the "Viennese Picture Manuscript" as a masterfully coded scientific book (Ibid.: 198).

In February 1936, Röck presented his results at the Institute of Ethnology at the University of Vienna. The title of his lecture was "Cipher Art and Astronomy in the Great Viennese Picture Manuscript from Mexico" (Röck, 1936a: [8]-[10]). At this ethnological session, Röck might have been quite satisfied with the feedback. He then contacted the Viennese press. On February 23,1936, the Sunday edition of the Neues Wiener Journal carried a column entitled: "Mystery of Mexican Pictorial Art Solved" (Anonymous, 1936: 11). Some weeks later, Röck published a similar article in the weekend edition of the Neue Wiener Tagblatt under his own name (Röck, 1936b: 7-8). Due to these sensational articles, the "Union of Correspondence from
Director Friedrich Röck (center) with employees of the Ethnological Museum Vienna, 1930 (Private Archive Bettina Hainschink, Vienna) 
the Foreign Press" became aware of the Viennese museum director. In June 1936, Röck was invited to the Ambassador Hotel in Vienna in order to present his scientific discoveries. ${ }^{29}$ Among the audience was a consul from the German embassy in Vienna. His name is not mentioned in the archival documents, but it was he who invited Röck to provide a proposal of his research results. ${ }^{30}$

Röck applied to the consul to publish his "deciphering findings and explanatory notes to the Codex Vindobonensis mexicanus 1 of approximately 1,200 printed pages in folio format" and to finance a "Research Institute for American Language and Antiquity" under his leadership in Vienna. ${ }^{31}$ Although Röck did not provide details of the costs, his application was discussed with Franz von Papen, the Cerman ambassador in Vienna. In this manner, contact was established with the Foreign Office in Berlin. The German Legation in Vienna saw the potential for a "great propaganda effect" in the publication project, which should be used for the foreign policy "interests of the Reich." ${ }^{32}$

However, the German SS research facility Ahnenerbe (Ancestral Heritage) intervened immediately. Created by Heinrich Himmler in July 1935, it also set up a department for the "examination of literature". Its scientific director, Walter Wüst, read Röck's article "Unraveling the Mexican Picture Manuscript" in the Cerman periodical Neue Woche of $1936 .{ }^{33}$ However, Wüst did not initiate a review procedure and instead expressed his personal disapproval. ${ }^{34}$

The Cerman Legation ignored Wüst's negative statement and urged the Ibero-American Institute in Berlin (IAI) to accept this "cultural-political issue." As a non-university research institution, the IAI, led by Wilhelm Faupel, was involved in Nazi foreign policy and maintained close diplomatic relations with Spain, Mexico, and Argentina (Cliech, 2003: 17-66). At the end of August 1936, Faupel suggested to the Reich Education Ministry (REM) ${ }^{35}$ that he would "release" the aforementioned publication, "if the costs of printing could be provided." ${ }^{36} \mathrm{As}$ an interim measure, the German Research Foundation (GRF) initiated a review procedure. The first request for an expert review was made to Georg Christian Thilenius, the long-standing director of the Ethnological Museum in Hamburg. ${ }^{37}$ In contrast to that of Wüst, his opinion was extremely positive. ${ }^{38}$

Surprisingly, the GRF could find no other experts willing to submit reviews despite repeated requests by the Reich Education Ministry. This was all the more significant, as Thilenius was not a specialist in ancient Mexican studies, but rather an expert on Oceania. The whole control procedure seemed to stall. Even when the Ibero-American Institute in Berlin invited Röck to give a lecture at the University of Berlin's Romance Seminary in May 1937, ${ }^{39}$ which was attended by the most renowned scholars of ancient America in Cermany, nothing changed (Röck, 1937: 356). Only when Max Uhle, "old master of American studies," intervened did Röck's Cerman colleagues finally agree to take a stand.
$29 \mathrm{BAB}, \mathrm{R} 73 / 14017$, f. $45-48$; Röck, Jun 3, 1936, lecture at the Ambassador Hotel, entitled "The Ancient Mexican Picture Manuscript of the Vienna National Library".

30 BAB, R73/14017, f. 42-44. Röck, Jun 18, 1936, proposal (exposé) to the consul.

31 Ibid

32 BAB, R73/14017, f. 41; Heinz, Jun 27, 1936, to the Foreign Office in Berlin. Hans Rüdiger von Heinz was a German embassy counselor in Vienna from 1934 to 1938 under von Papen.

$33 B A B, N S 21 / 2116$, fs. 756-758; Friedrich Röck, Die altmexikanische Bilderhandschrift der Wiener Nationalbibliothek. Neue Woche, 25, p. 30 (Jun 17, 1936) (Röck, 1936c).

34 BAB, NS21/2116 Röck, f. 750; Wüst, Jul 1, 1936, handwritten note.

35 Officially called "German Ministry of Science, Education and Popular Education".

$36 \mathrm{BAB}, \mathrm{R} 73 / 14017$, f. 40 ; Faupel, Aug 21, 1936, to the REM.

$37 \mathrm{BAB}, \mathrm{R} 73 / 14017$, f. 38 ; GRF, Oct 23,1936 , to Thilenius.

38 BAB, R73/14017, fs. 35-36; Thilenius, Nov 2,1936, to the GRF.

39 Officially called "German Ministry of Science, Education and Popular Education". 


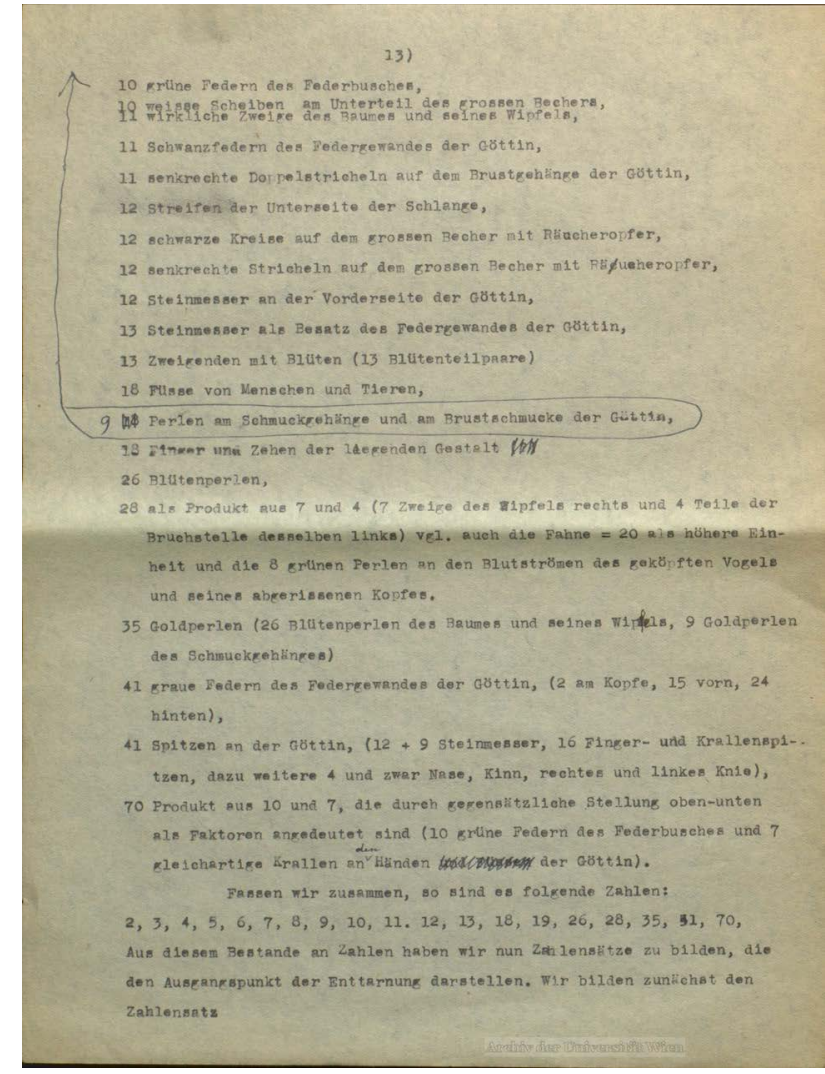

On October 18, 1937, Uhle presented all reviews he had managed to gather to the Cerman Research Foundation, partly compiled by phone calls..$^{40} \mathrm{As}$ all reviewers had reported doubts and concerns, their judgments were devastating. Konrad Theodor Preuss, who had led the North and Central America Department of the Ethnological Museum of Berlin since 1920 and had also attended Röck's lecture in Berlin, commented on his decoding technique in the following way: "The manner of his research did not immediately make sense to many listeners including myself. In particular, the argumentation of his number series, of seemingly irrelevant details, in the pictures often appears arbitrary." "Even Paul Schellhas, a Berlin lawyer and Maya expert who had spent decades deciphering the Mayan hieroglyphs, could not agree with Röck's findings: "On the contrary, I think that they are very doubtful and sometimes downright imaginary." ${ }^{42}$ Schellhas regarded Röck's assumption that "priests" had "disguised" their astronomical knowledge in the manuscript as "completely arbitrary and in no way proven." ${ }^{43} \mathrm{He}$ convincingly argued that "camouflage" was "superfluous" as at that time there were "hardly any copies of such precious manuscripts." "His judgment had weight as it was published in the prestigious Zeitschrift für Ethnologie (Ethnological Journal) shortly thereafter in the context of a serious historical essay on Mayan research (Schellhas, 1937: 382). Negative statements of a similar kind were also given by the Cerman ancient Americanists F.W. Hans Ludendorff, Walter Lehmann,
Details from Röck's manuscript for his lecture in Berlin, May 31, 1937, demonstrating his deciphering procedure to count material items (VUA, FRP, 131.104.21)

40 BAB, R73/14017, f. 24; IAI, Oct 18,1937 , to the GRF

41 BAB, R73/14017, f. 24; IAI, Oct 18,1937 , to the GRF

42 BAB, R73/14017, f. 24; IAI, Oct 18,1937 , to the GRF.

43 Ibid.

44 Ibid. 
Robert Lehmann-Nitsche, and Max Uhle. There is no evidence of Nazi ideological influence in any of these reviews.

Röck's reputation as an ancient Mexicanist was already badly damaged, even before the incorporation of Austria into Nazi Germany on March 12, 1938, known as the Anschluss. In order to salvage his scientific reputation, he appointed doctoral students to verify his deciphering procedure. All of them were members of the Nazi Party, which prior to 1933 had been banned in Austria. Röck himself was ideologically close to the Nazi Party, he even tried to join, but he never officially became a member. According to Johann Leopold Ehm and Adolf Anton Plügel, Röck's indoctrination of his students was successful. ${ }^{55}$ However, his strategy ultimately failed with Karl Anton Nowotny, a postal official from Hollabrunn, who studied anthropology at the University of Vienna since the beginning of 1935 and devoted himself to "ancient American cultural problems." ${ }^{46}$

\section{NOWOTNY DISTANCED HIMSELF FROM RÖCK'S “DECIPHERING PROCEDURE”, 1939}

Röck forced Nowotny to write a commentary on the Codex Laud as a dissertation topic. However, Nowotny distanced himself from Röck's method of deciphering, as the following passage shows: "It is therefore necessary to point out once again that the following, second part of the work is most strongly committed to Prof. F. Röck and that it is based on the methods of Prof. F. Röck, not those of the author" (Nowotny, 1939a: 166).

Nowotny was the one who clarified Seler's astronomical speculations during the post-war period (Nowotny, 1961:122). He drew an ethnographic analogy with modern ritual practices in Cuerrero in Mexico in order to interpret the codex pages as protocols for rituals (Boone, 2007: 161-162) and showed that the religious codices had no occult astronomical content. However, Nowotny never carried out ethnographic fieldwork in Mexico, but his mature work played "a central role in elaborating a new paradigm" in ancient Mexican studies (Jansen, 2017: 443; cf. Everett; Sisson, 2005: xix-xxi).

In his report on Nowotny's dissertation, Röck ignored the criticism of his student and emphasized that the candidate had carried out the description and explanation of the image section of the Codex Laud "as well as the deciphering of its astronomical content on the basis of the deciphering procedure [...] set up by the supervisor" done "with scientific meticulousness." ${ }^{47}$ Nowotny would probably not have agreed with this verdict. Röck used his comments on Nowotny's dissertation as an opportunity to justify his approach in the face of his Cerman colleague's attacks.

Against this background, it is relevant to explain Nowotny's position on National Socialism. Research on his early biography has received little attention
45 See Ehm (1938); VUA, PH RA 13.922; Röck, dissertation report, Jun 17, 1938; see Plügel (1939); VUA, PH RA 14.992; Röck, dissertation report, Jun 6, 1939.

46 NARA II/T580/A3359; NS Personalfragebogen, K. A. Nowotny, Traun, May 21, 1938 I thank Andre Gingrich who has made available this entire archival record.

47 VUA, PH RA 14.855; Röck, dissertation report, Apr 11, 1939. 
so far (Cohm-Lezuo, 2014: 84; Jansen, 2017: 443) but archival documents clearly show that Nowotny was a radical supporter of Nazi ideology. He joined the Nazi Party in 1932 and lost his job in 1934 after the ban on National Socialism in Austria. ${ }^{48} \mathrm{He}$ mentioned his "participation in a demonstration" as well as "a series of anonymous ads for Nazi occupation at the post office in Stockerau [Lower Austria]" as a reason for this. ${ }^{49}$ In June 1935 he interrupted his university studies and fled to Berlin. Initially, he received "temporary" support from the Nazi Refugee Relief Organization and later, according to him, was active "in Ceneral Göring's regiment. ${ }^{5_{50}}$ The exact time of his return to Vienna is unknown. After the Anschluss, he acted as the "chief executive officer" at Hollabrunn. ${ }^{.1}$ Nowotny carried out several months of research for the Cerman Ancestral Heritage (SS Ahnenerbe) and received a monthly grant of 140 . Reichsmark from November 1938 until March 1939. ${ }^{.2}$ He published his findings in the journal Cermanien, which was also edited by the SS Ahnenerbe (Nowotny, 1939b: 218-225). At the same time, he contributed the article "Myth or Magic in Cermanic Antiquity?" to the Nationalsozialistische Monatshefte, a political Nazi magazine published by the Amt Rosenberg. ${ }^{53}$ This article concluded with a favorable quote from one of Adolf Hitler's key speeches (Nowotny, 1939c: 248).

After graduating from the University of Vienna in April 1939, Nowotny used his connections in the Nazi state in order to gain a respectable career. At the outbreak of World War II he moved to Krakow, capital of the General Covernment (now Poland). ${ }^{54}$ There, he held a leading position in the Department of Science and Education for Museums. ${ }^{55}$ After the war ended, Nowotny was incarcerated and he subsequently returned to Vienna in 1946. With a letter of discharge from Jan Tadeusz Kowalski, secretary of the Polish Academy of Sciences, Nowotny did not have to undergo "denazification"56 and in 1947 he was given a job as a research assistant at the Ethnological Museum in Vienna (Gohm-Lezuo, 2014: 84-85).

\section{ANCIENT MEXICAN STUDIES AND THE "CULTURE-COMPARATIVE EXHIBITION" OF 1942}

After the Anschluss, despite his attempt to join the Nazi Party, Röck was subjected to fierce attacks as the director of the Ethnological Museum. The Nazi cultural authority Reich Government III intended to replace Röck with the Austrian anthropologist Hugo Adolf Bernatzik. ${ }^{57}$ However, Röck successfully defended his post and was supported by the personal network he had built long before the Anschluss. His newly strengthened position enabled him to organize a major exhibition in order to demonstrate his deciphering procedure to the public.

On March 2, 1942, the "culture-comparative exhibition," curated by Röck, opened at the Vienna Ethnological Museum in the presence of representatives of the Nazi Party, the Cerman state, and the army (Wehrmacht). Röck had in-
48 Elsewhere Nowotny gave the date of his entry as "December 1933" (see NARA II/T580/A3359; NS Personalfragebogen, Nowotny, May 21, 1938).

49 VUA, PH RA 14.855; Karl Anton Nowotny, CV, no date [1939].

50 NARA II/T580/A3359; NS Personalfragebogen, K. A. Nowotny, Traun, May 21, 1938 Nowotny's task within this regiment cannot be precisely determined due to illegibility.

51 VUA, PH RA 14.855; Nowotny, CV, no date [1939].

52 BAB, NS21/1984, f. 648; Wüst, Oct 21, 1938, to Nowotny, Hollabrunn. Nowotny contributed the topic "The Birch" for the SS research project "Forest and tree in the Aryan-Germanic history of ideas and culture".

53 This was an official body for cultural policy and surveillance within the Nazi party, headed by Alfred Rosenberg (see Bollmus, 1970)

\section{The General} Governement was a German zone of occupation established after the joint invasion of Poland by Nazi Germany and the Soviet Union in 1939 at the onset of the Second World War.

55 Hansen 1994: 589. His exact field of responsibility in Krakow has not yet been investigated.

56 ÖStA, AdR, K 19/77 Präsidium; Kowalski, Kraków, Jul 7, 1947.

57 ÖStA, AdR, BKA-Inneres, Reichsstatthalterei III, 78.220/1939; Otto Koller, Jun 9, 1938 , to the Reich Commissioner for Cultural Affairs. 
vested greatly in the exhibition, as it gave him the first opportunity to present his life's work in the field of astral calendars. The topics ranged from calendar systems and ornamental signs of orientation (Ortung) to star constellations and astronomical "camouflage" (Röck, 1942: 12-15).

The major aim of the exhibition was to restore Röck's reputation in ancient Mexican studies. The highlight, presented at the end of the tour, was the Codex Vindobonensis I, renamed Codex Kreichgauer. Undoubtedly, the last hall demonstrated Röck's "deciphering procedure" as a grand finale. Röck had organized twelve blackboards to explain the rules of encrypted astronomy to the ultimate detail..$^{5}$ The first step of this method was based on counting various symbols. Then, abstract number series were generated and, finally, after applying the basic types of mathematical calculation, the astronomical data was produced. This sophisticated procedure was exemplified in almost all of the fifty-two codex sheets. Special attention was given to sheet fifty-one, since according to Röck, it contained the exact number of the synodic orbital period of Saturn with a duration of 377.75 days. ${ }^{59}$ The extremely text-heavy display boards, with their elaborate arithmetic operations, probably only served to reconfirm to visitors what Röck's colleagues had already identified in their reviews in 1937: his deciphering method was based on number acrobatics, which were incom-

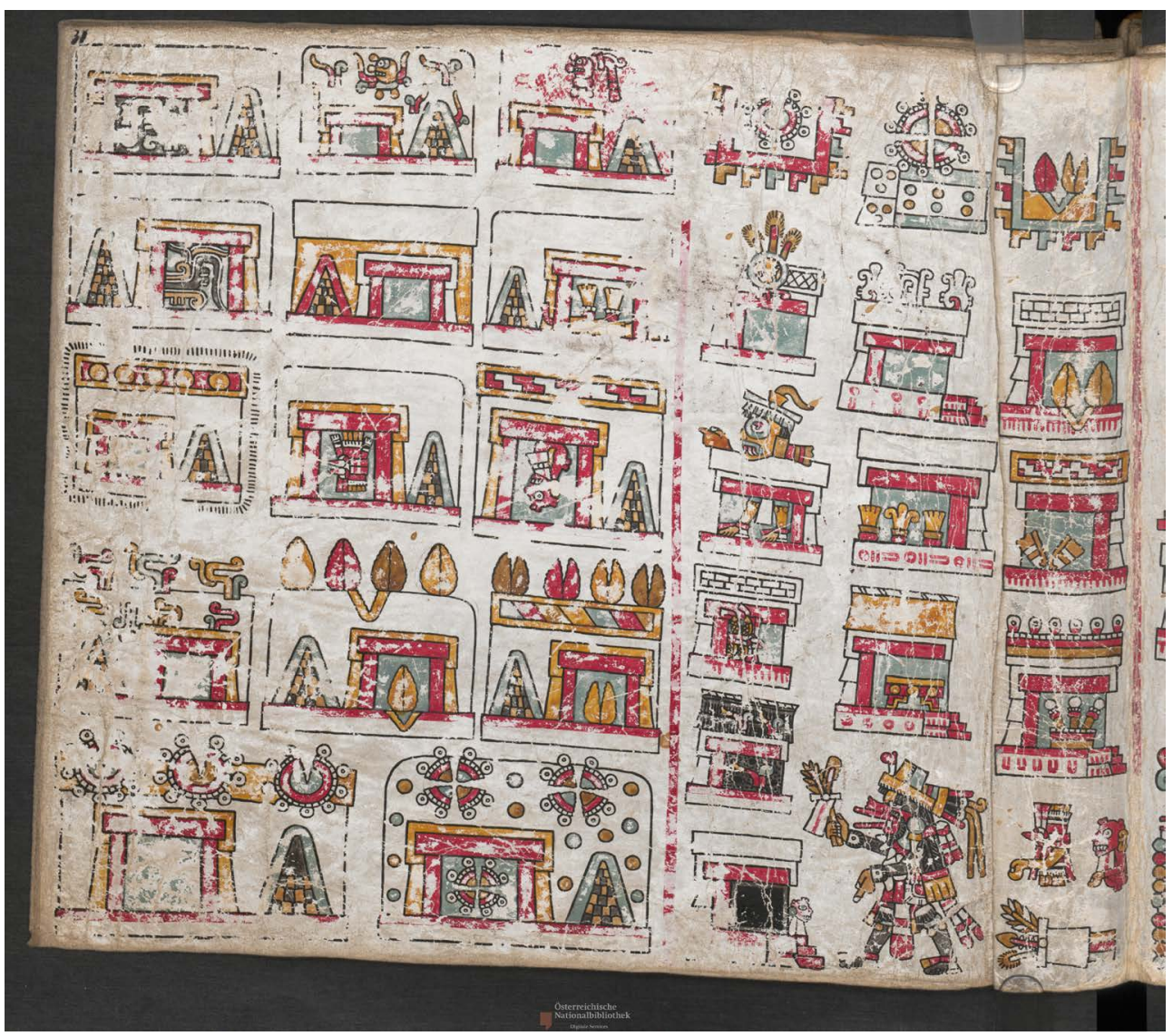

58 VUA, FRP, 131.104.2; photographs for the blackboards in room 6.

\section{Figure 5}

A slide page of the famous Codex Vindobonensis I (ÖNB/ Wien, Cod.mex.1, pag. 31) Röck misinterpreted these temples as "twenty-eight Toltec lunar houses" (VUA, FRP, 131.104.2) 
prehensible to anyone but him. Ancient American scholars simply ignored the exhibition. Not a single scientific review of the "culture-comparative exhibition," which ran until September 1944, is known.

On June 7, 1945, Röck was discharged from his posts by the Austrian authorities and had to undergo a "denazification" procedure. Röck had wanted to join the Nazi party in 1938, but ultimately, he simply remained a party candidate. He was judged free of National Socialist sentiments. ${ }^{60}$ Since Röck had already passed the age limit of 65 , he retired. Nevertheless, he persisted in claiming the veracity of his deciphering method into old age. ${ }^{61}$ All the more tragic is the fact that since World War II, the astral interpretation of myths in ancient Mexican studies has generally been regarded as a scientific aberration. ${ }^{62}$ In 1949, the Mexican archaeologist Alfonso Caso began to work on a genealogical-historical interpretation (Caso, 1949: 145-186), which Karl Anton Nowotny and his student Ferdinand Anders joined in developing. ${ }^{63}$ Nowotny based this new interpretation on the ethnographic observations of the German zoologist and linguist Leonhard Schultze-Jena, who between 1929 and 1931 visited a number of Mesoamerican communities and recorded oral traditions (Jansen; Pérez; Jiménez, 2017: 444).

\section{CONCLUSION}

Eduard Seler from Berlin laid the foundations for astronomical and calendar -oriented ancient Mexican studies in Austria during the First World War. The Steyler missionary Damian Kreichgauer worked in St. Gabriel near Mödling on the thesis that the ancient Mexican manuscripts were intentionally "coded" by a priest elite. Although the Seler School in Berlin rejected this reorientation, Friedrich Röck drew on Kreichgauer's work. Röck built his scientific career in an environment of völkisch-minded ancient Assyriologists who wanted to establish a "pan-Aryan Orient" comparable to the previous "pan-Babylonism." Röck adopted the astral-Elamite approach of the Prussian schoolteacher Ferdinand Bork and transferred it to ancient Mexican studies. He developed a trans-Pacific approach that would show "lost cultural connections between the Old and the New World" (Röck, 1925: 142-152). Based on his theosophical-mystical worldview, Röck elaborated an opaque deciphering system for ancient Mexican manuscripts. In June 1936, he received an offer from the German Legation in Vienna, who wanted to exploit Röck's results for Nazi science policy, but this never came to fruition because Cerman ancient Mexican scholars rejected Röck's method as unscientific. Karl Anton Nowotny was an early critic who distanced himself from "Röck's method" in his own dissertation, which was supervised by Röck. Thus, Nowotny created an important basis for the genealogical-historical and ethno-
60 ÖStA, AdR, BMfU, PA Röck, f. 134; Resolution of the Special Commission of the First Instance of the State Office for Volksaufklärung, for Education and Cultural Affairs: "Assessment according to $\S 21$ of the Prohibition Act", Nov 15, 1945

61 In the post-war period, Röck published his deciphering procedure in the periodical Sternbilder, edited by the Austrian sci-fi writer Erich Dolezal (Röck 1948: 104-115).

62 Kudlek 1972: 431; Anders/ Jansen/García 1992; Anders 2005: xi; see also Steinle 1995: 74

63 An important Nowotny student is also Johanna Broda (born 1943), who graduated from the University of Vienna in 1967 (Broda de Casas 1967). With her longstanding professorship at the National Autonomous University of Mexico (UNAM), she is by far one of the most well-known experts in Archaeoastronomy, Calendrics and Sacred Geography in ancient Mesoamerica. 
graphic interpretation of Mexican codices in the post-war period. The fact that Nowotny belonged to the Nazi Party as early as 1932 and had accepted research assignments from the German Ancestral Heritage (SS Ahnenerbe), after the 1938 Anschluss, has previously been unknown and is perhaps one of the most surprising findings of this study. A former Nazi modernized ancient Mexican studies in Austria. Since the retirement of Ferdinand Anders, this previously well-established discipline at the University of Vienna is currently no longer represented.

Peter Rohrbacher, PhD in Vienna 2001, is a postdoctoral researcher at the Institute for Social Anthropology of the Austrian Academy of Sciences in Vienna. His work focuses on the history of anthropology and on African studies. At the moment, he is co-editor of the book project "Viennese Ethnology in the Nazi Period" (in collaboration with Andre Gingrich, forthcoming).

\section{BIBLIOGRAPHY}

\section{Archival Collections}

\section{Bundesarchiv (BAB), Berlin-Lichterfelde (German Federal Archives)}

NS21/1984 Karl Anton Nowotny

NS21/2116 Friedrich Röck

R73/14017 Friedrich Röck

\section{The National Archives at College Park (NARA II), Maryland}

T 580/A3359 Karl Anton Nowotny

\section{Österreichisches Staatsarchiv (ÖStA), Vienna (National Archives of Austria)}

Archiv der Republik (AdR)

Bundesministerium für Unterricht (BMfU), Personalakt (PA) Friedrich Röck

Bundeskanzleramt (BKA)-Inneres, Reichsstatthalterei III, 78.220/3

K 19/77 Präsidium, Karl Anton Nowotny

Private Archive Ferdinand Anders (PA Anders), Klosterneuburg

Friedrich Röck, student notebook, 1906-1907, 264 pages 


\section{Vienna University Archive (VUA), Vienna}

Friedrich Röck papers (FRP)

131.104.2 Museum für Völkerkunde

131.104.21 Literatur und Bibliographie

Philosophische (PH) Fakultät (Philosophical Faculty)

PH PA 3.052 Friedrich Röck

PH Rigorosenakt (RA) 13.922 Johann Ehm

PH RA 14.855 Karl Anton Nowotny

PH RA 14.992 Anton Adolf Plügel

S 304.1056

\section{Published Works}

ANDERS, Ferdinand; JANSEN, Maarten; and REYES GARCÍA, Luis [Comisión Técnica Investigadora]

1992 Origen e historia de los reyes Mixtecos. Libro explicativo del llamado Códice Vindobonensis. México. D.F., Fondo de Cultura Económica/Graz, ADEVA.

ANDERS, Ferdinand

2005 "Foreword". In EVERETT, George A. and SISSON, Edward B. (eds. and translators). Karl Anton Nowotny, Tlacuilolli: style and contents of the Mexican pictorial manuscripts with a catalog of the Borgia Group. Norman, University of Oklahoma Press, pp. xi-xiii.

\section{ANONYMOUS}

1936 "Wiener entziffert Runen einer versunkenen Welt.

Geheimnis der mexikanischen Bilderschrift gelöst". Neues

Wiener Journal [Vienna], 44:11 [February 23, 1936].

BLAVATSKY, Helena Petrovna

1899 [1888] Die Ceheimlehre. Die Vereinigung von Wissenschaft, Religion und Philosophie. Band I, Kosmogenesis. 3rd ed. Den Haag, J.J. Couvreur. 
BOCKHORN, Olaf

1994 "Von Ritualen, Mythen und Lebenskreisen: Volkskunde im Umfeld der Universität Wien". In JACOBEIT, Wolfgang, LIXFELD Hannsjost and BOCKHORN, Olaf (eds.) Zusammenarbeit mit DOW, James R. Völkische Wissenschaft. Cestalten und Tendenzen der deutschen und österreichischen Volkskunde in der ersten Hälfte des 20. Jahrhunderts. Helmut Paul Fielhauer + gewidmet. Wien/Köln/Weimar, Böhlau, pp. 477-526.

BOLLMUS, Reinhard

1970 Das Amt Rosenberg und seine Cegner: Studien zum

Machtkampfim Nationalsozialistischen Herrschaftssystem.

Stuttgart, Deutsche Verlags-Anstalt.

BOONE, Elizabeth Hill

2007 Cycles of Time and Meaning in the Mexican Books of Fate. Austin, University of Texas Press.

BORK, Ferdinand

1910 "Das Venusjahr". Memnon, 4: 83-105.

1914 "Tierkreisforschungen". Anthropos, 9 (1-2): 66-80.

BRODA DE CASAS, Johanna

1967 Der mexikanische Kalender und eine Analyse der Jahresfeste bei Diego Duran. Vienna, PhD dissertation, Universität Wien.

BUCHWALD, Jed Z. and JOSEFOWICZ, Diane Greco

2010 The Zodiac of Paris: How an Improbable Controversy over an Ancient Egyptian Artifact Provoked a Modern Debate Between Religion and Science. Princeton, Princeton University Press.

CASO, Alfonso

1949 "El mapa de Teozacoalco". Cuadernos Americanos, 47 (5): 145-181.

EHM, Johann

1938 Das Werktum im Codex Nuttall mit besonderer Berücksichtigung der Darstellungsweise. Vienna, PhD dissertation, Universität Wien. 
EVERETT, George A. and SISSON, Edward B.

2005 "A note on the Author: Karl Anton Nowotny". In: EVERETT, George A. and SISSON, Edward B. (eds. and translators). Karl Anton Nowotny, Tlacuilolli: style and contents of the Mexican pictorial manuscripts with a catalog of the Borgia Croup. Norman, University of Oklahoma Press, pp. xix-xxi.

GINZEL, Friedrich

1906 Handbuch der mathematischen und technischen Chronologie. Das Zeitrechnungswesen der Völker. Band 1. Leipzig, Hinrichs.

CLIECH, Oliver

2003 "Lateinamerikanische,Multiplikatoren' im Visier. Kulturpolitische Konzeptionen für das Ibero-Amerikanische Institut zum Zeitpunkt seiner Cründung". In LIEHR, Reinhard, MAIHOLD, Günther and VOLLMER, Günter (eds.). Ein Institut und sein Ceneral. Wilhelm Faupel. Frankfurt am Main. Vervuert, pp. 17-66.

GOHM-LEZUO, Julia

2014 Die Studierenden der Völkerkunde an der Universität Wien 19371945. Vienna, PhD dissertation, Universität Wien.

FRAZER, James Gordon

1906-1915 The Golden Bough: A Study in Comparative

Religion. 12 vols. 3 rd ed. London, Macmillan.

HANSEN, Georg (ed.)

1994 Schulpolitik als Volkstumspolitik: Quellen zur Schulpolitik der Besatzer in Polen 1939-1945. Münster, Waxmann/New York.

HOSKIN, Michael

1999 "Astronomy in Antiquity". In HOSKIN, Michael (ed.). The Cambridge Concise History of Astronomy. Cambridge, Cambridge Univ. Press, pp. 18-47.

JANSEN, Maarten and PÉREZ JIMÉNEZ, Gabina Aurora

2017 Time and the Ancestors: Aztec and Mixtec ritual art. Leiden, Brill.

KOFLER, Christine (ed.)

1975 Karl Röck: Tagebuch 1891-1946. Drei Bände. PhD dissertation, Universität Innsbruck. 
KRAUS, Johann

1962 P. Damian Kreichgauer SVD, 1859-1940. Im Auftrag der Obern zusammengestellt. Kaldenkirchen, Steyler.

KREICHCAUER, Damian

1914 Les Mythologies et les Calendriers de l'ancien Mexique.

Semaine d'Ethnologie religieuse II. Session tenue à Louvain (27

Août-5 Septembre 1913). Paris, Beauchesne, pp. 315-333.

1915-1916 "Die Astronomie des Kodex Nuttall. Ein Beitrag zur

Kulturgeschichte Zentralamerikas". Anthropos, 10-11 (1-2): 1-23.

1917 Die Astronomie in der großen Wiener Handschrift aus Mexiko. Wien, Alfred Hölder, pp. 1-52. (Sitzungsberichte der Kaiserlichen Akademie der Wissenschaften in Wien, Philosophisch-Historische Klasse 182, 5).

KUDLEK, Manfred

1972 "A statistical analysis of dates on Maya monuments to find astronomical inscriptions". Atti del XL Congresso Internazionale degli Americanisti, 3-10 settembre, 1972, Roma, Tomo 1. Genova, Tilgher: 431-432.

KUCLER, Franz Xaver

1907 "Kulturhistorische Bedeutung der babylonischen Astronomie". Vereinsschrift der Cörres-Cesellschaft Bd. 2, pp. 38-50.

LEHMANN, Walter

1929 "Beschreibung der Handschrift". In: Nationalbibliothek in Wien (ed.). Codex Vindobonensis Mexic. 1 - Faksimileausgabe der mexikanischen Bilderhandschrift der Nationalbibliothek in Wien. Eingeleitet durch Walter Lehmann und Ottokar Smital. Wien, Schroll, pp. 13-42.

LINIMAYR, Peter

1993 Das Institut für Völkerkunde der Universität Wien 1938-45 unter Mitberücksichtigung des Museums für Völkerkunde Wien. Band 2 (Quellenteil). Vienna, Master's thesis, Universität Wien.

1994 Wiener Völkerkunde im Nationalsozialismus. Ansätze zu einer NS-Wissenschaft. Frankfurt am Main, Peter Lang.

LUKSCH, Katharina

2015 Die Zeichen Anderer betrachten. Europäische Perspektiven aufein mixtekisches Manuskript. Wien, LIT Verlag. 
NOWOTNY, Karl Anton

1939a Kommentar zum Codex Laud. Vienna, PhD dissertation, Universität Wien.

1939b "Runen und Sinnbilder". Cermanien. Monatshefte für Cermanenkunde zur Erkenntnis deutschen Wesens, 2 (5): 218-225.

1939C "Mythen und Zauberei im germanischen Altertum". Nationalsozialistische Monatsblätter, 10: 238-248.

1961 Tlacuilolli: die mexikanischen Bilderhandschriften, Stil und Inhalt; mit einem Katalog der Codex-Borgia-Cruppe. Berlin, Mann.

NOWOTNY, Karl Anton (ed.)

1967 Agrippa von Nettesheim, Heinrich Cornelius. De occulta philosophia. Graz, ADEVA.

PLÜGEL, Anton Adolf.

1939 Beiträge zum gestirn- und zeitwährungskundlichen Inhalt der Rückseite des Codex Nuttall einer altmexikanischen Bilderhandschrift. Vienna, PhD dissertation, Universität Wien.

RANZMAIER, Irene

2013 Die Anthropologische Gesellschaft in Wien und die akademische Etablierung anthropologischer Disziplinen an der Universität Wien 1870-1930. Köln/Weimar/Wien, Böhlau Verlag.

RÖCK, Friedrich

1910 "Die Platonische Zahl und der altbabylonische Ursprung des indischen Yuga-Systems". Zeitschrift für Assyriologie, 24: 318-330.

1911 Studien zur babylonischen-assyrischen Mythologie. Innsbruck, PhD dissertation, Universität Innsbruck.

1913 "Der Palaeozodiakus, die prähistorische Urform unseres Tierkreises". Memnon, 6: 147-176.

1915 "Der Denarzyklus des Agrippa von Nettesheim". Orientalische Literaturzeitung, 16 (8): 356-362.

1919-1920 "Die Cötter der sieben Planeten im alten Mexiko und die Frage eines alten Zusammenhanges toltekischer Bildung mit altweltlichen Kultursystemen". Anthropos, 14-15 (3-4): 1080-1098.

1922 "Kalender, Sternglaube und Weltbilder der Tolteken als Zeugen verschollener Kulturbeziehungen zur Alten Welt". Mitteilungen der Anthropologischen Cesellschaft in Wien, LII: 43-135. 
1925 "Eine verschollene Kultureinheit der Alten und der Neuen Welt". Die Bildung, I (5): 142-152.

1935 "Ein altindianisches Bilderbuch". Frohes Schaffen, 12: 193-204.

1936a Chiffrierkunst und Astronomie in der großen Wiener Bilderhandschrift aus Mexiko. Ethnologische Fachsitzung am 6. Februar 1936 (Cemeinsam mit der Arbeitsgemeinschaft der Amerikanisten in Wien). Mitteilungen der Anthropologischen Cesellschaft in Wien, LXVI: [8]-[10].

1936b "Das Geschenk des Kaisers. Die Geheimnisse einer alttoltekischen Bilderhandschrift". Neues Wiener Tagblatt, 15: 7-8 [11. April 1936].

1936C "Die altmexikanische Bilderhandschrift der Wiener Nationalbibliothek". Neue Woche, 25: 30 [17. June 1936].

1937 "Cetarnte Himmelskunde in altmexikanischen Bilderhandschriften". Forschungen und Fortschritte, 13: 356-357 [20. Oktober 1937].

1942 Führer durch die kulturvergleichende Ausstellung des Museums für Völkerkunde in Wien. Wien, Selbstverlag des Museums für Völkerkunde.

1948 "Astronomie in Bilderschrift". Sternkalender, 2: 104-115.

SCHELLHAS, Paul

1937 "Fünfzig Jahre Mayaforschung. Ein Epilog". Zeitschrift für Ethnologie, 69: 365-389.

SCHMIDT, Wilhelm

1908 "Panbabylonismus und ethnologischer Elementargedanke". Mitteilungen der Anthropologischen Gesellschaft in Wien, XXXVIII: 73-91.

SCHULTZ, Wolfgang

1910 "Cesetze der Zahlenverschiebung im Mythos und in mythenhaltiger Überlieferung". Mitteilungen der Anthropologischen Cesellschaft in Wien, XXXX: 101-150.

SELER, Eduard

1904-1909 Codex Borgia, eine altmexikanische Bilderschrift der Bibliothek der Congregatio de Propaganda Fide. Band 1-3. Berlin, Unger.

STEINLE, Robert

1995 Möglichkeiten und Ansatzpunkte zum Verständnis fremder Kulturen, dargestellt am Fallbeispiel Altmexikos: ein Beitrag zur Methodik der Beziehungsforschung oder Frage lokalbezogener Deutbarkeit. Vienna, Master's theses, Universität Wien. 
SPECIAL ISSUE | Peter Rohrbacher | Encrypted Astronomy, Astral

STUCKEN, Eduard

1913 Der Ursprung des Alphabets und die Mondstationen. Leipzig, Hinrichs.

WEICHENHAN, Michael

2016 Der Panbabylonismus: die Faszination des himmlischen Buches im Zeitalter der

Zivilisation. Berlin, Frank \& Timme, Verlag für wissenschaftliche Literatur.

WEIDNER, Ernst

1963 "Ferdinand Bork (26. November 1871 bis 28. Februar 1962)". Archiv für Orientforschung, 20: 304-305.

Received on August 9, 2018. Accepted on December 14, 2018. 